\title{
Whole-body fluxes and partitioning of amino acids to the mammary gland of cows fed fresh pasture at two levels of intake during early lactation
}

\author{
D. Pacheco ${ }^{1,2}$ †, M. H. Tavendale ${ }^{1}$, G. W. Reynolds ${ }^{3}$, T. N. Barry ${ }^{3}$, J. Lee ${ }^{1}$ and \\ W. C. McNabb ${ }^{1} *$ \\ ${ }^{1}$ Nutrition and Behaviour, AgResearch Ltd, Grasslands Research Centre, Private Bag 11008, Palmerston North, \\ New Zealand \\ ${ }^{2}$ Institute of Food, Nutrition and Human Health, Massey University, Private Bag 11222, Palmerston North, \\ New Zealand \\ ${ }^{3}$ Institute of Veterinary, Animal and Biomedical Sciences, Massey University, Private Bag 11222, \\ Palmerston North, New Zealand
}

(Received 6 December 2001 - Revised 20 February 2003 - Accepted 11 March 2003)

\begin{abstract}
The utilisation of essential amino acids (EAA) by the mammary gland of lactating dairy cows fed fresh forages was studied to provide basic information useful in designing strategies to increase the production of milk protein from pasture-fed dairy cows. The relationship between the flux of EAA in the whole body and their uptake by the mammary gland was determined in four cows in early lactation (length of time in milk 44 (SD 14.5) d) producing 21 (SD 4.0) kg milk/d. The cows were maintained in metabolism stalls and fed fresh perennial ryegrass (Lolium perenne) and white clover (Trifolium repens) pasture ad libitum or restricted to $75 \%$ ad libitum intake. The whole-body fluxes of amino acids (AA) were measured using an arterio-venous infusion of universally ${ }^{13} \mathrm{C}$-labelled AA. Whole-body fluxes of fourteen AA were estimated. Isotope dilution indicated that mammary utilisation accounted for one-third of the whole-body flux of EAA, with individual AA ranging between 17 and $35 \%$. Isoleucine, leucine, valine and lysine were the EAA with the greatest partitioning towards the mammary gland (up to $36 \%$ of the whole-body flux), which could reflect a potentially limiting effect on milk protein synthesis. In the case of AA with low partitioning to the mammary gland (for example, histidine), it is suggested that non-mammary tissues may have priority over the mammary gland and therefore the supply of this AA may also limit milk protein synthesis.
\end{abstract}

Mammary gland: Amino acid metabolism: Dairy cows: Pasture diets

The characterisation of amino acid (AA) utilisation by the mammary gland is an initial step towards the development of strategies for increasing the output or changing the relative proportions of proteins secreted in the milk of lactating dairy cows. It is well understood that the nutrients reaching the mammary gland are ultimately the result of complex interactions between organs and tissues in the whole body. With their concept of homeorhesis, Bauman \& Currie (1980) described lactation as the result of a series of metabolic controls, which orchestrate a prioritisation of tissues and organs in terms of the relevance of their metabolic function at a particular stage. A major effect of these controls is the diversion (partitioning) of nutrients from other tissues to the mammary gland to sustain lactation, sometimes at the expense of other bodily functions (Champredon et al. 1990).

Although the concept of partitioning is generally accepted for various nutrients and physiological states, there is little quantitative assessment of its magnitude in terms of AA metabolism in lactating dairy cows, particularly when fed fresh forage diets. Most of the current feeding systems and nutrient requirement guidelines (AFRC, 1993; National Research Council, 2001) propose that the rates of partitioning to the mammary gland and utilisation for milk protein synthesis are the same for all AA. However, even in the most comprehensive studies, only

\footnotetext{
Abbreviations: AA, amino acid; BCAA, branched-chain amino acid; DMI, DM intake; EAA, essential amino acid; GIT, gastrointestinal tract; Gln, glutamine; Glu, glutamic acid; His, histidine; IE, isotopic enrichment; Ile, isoleucine; ILR, irreversible loss rate; Leu, leucine; Lys, lysine; Met, methionine; Phe, phenylalanine; Ser, serine; TBDMS, N,O-tert-butyldimethylsilyl; Thr, threonine; Tyr, tyrosine; Val, valine.

* Corresponding author: Dr Warren C. McNabb, fax + 646351 8003, email warren.mcnabb@agresearch.co.nz

$\dagger$ Present address: Dairy and Swine Research and Development Center, Agriculture and Agri-Food Canada, PO Box 90,2000 route 108 East, Lennoxville, Québec, Canada JIM 1 Z3.
} 
the partitioning of a limited number of AA, often in isolation, has been studied in dairy cows (Bruss \& Black, 1982; Black et al. 1990; Boirie et al. 1995).

One way to measure the total body flux of an AA in animals is by quantifying the dilution of a tracer substance (Reeds, 1992; Lobley, 1993). Both radioactive (Hammond et al. 1987; Lobley et al. 1987; Crompton \& Lomax, 1993) and stable isotopes (Bequette et al. 1994; Liu et al. 1995; Lapierre et al. 1996, 1999) have been used to label AA for this purpose. A technique using the infusion of a mixture of ${ }^{13} \mathrm{C}$-universally labelled AA of algal origin has allowed the simultaneous estimation of the whole-body fluxes of an array of AA. Using this technique, several studies have been conducted to study the proportional impact of specific organs and tissue beds on the wholebody metabolism of AA in sheep (Lobley et al. 1996) and dairy goats (Bequette et al. 1997). However, no information is available on the simultaneous estimation of the partitioning of AA in lactating dairy cows.

The present paper describes the measurement of the whole-body AA fluxes in lactating dairy cows fed fresh perennial ryegrass (Lolium perenne)- and white clover (Trifolium repens)-dominant pasture. These fluxes were then related to the mammary utilisation of AA to estimate the partitioning of individual AA towards milk protein synthesis. In that way, it provided, first, a characterisation of the whole-body AA fluxes in lactating cows fed fresh pasture and, second, more information to identify those AA that may limit the synthesis of milk proteins.

\section{Materials and methods}

\section{Animals and diets}

Four lactating Friesian cows in early lactation were assigned to one of two levels of DM intake (DMI) in a $2 \times 2$ crossover design (ad libitum and $75 \%$ ad libitum intake). The average time in milk of the cows was 44 (SD 14.5) d with the average live weight being 498 (SD 64.2) kg at the beginning of the experiment. The experiment consisted of two $16 \mathrm{~d}$ experimental periods comprising a $5 \mathrm{~d}$ period for diet adaptation and an $11 \mathrm{~d}$ period for measurement of milk production and composition, DMI and feed composition. During this period, faeces and urine were collected, sampled and analysed as described by Carruthers \& Neil (1997) for N balance measurements. Animals were fed individually and maintained outdoors from day 1 to 5 , and in individual metabolism stalls from day 6 to 16 at the Dairy Centre of Excellence facilities in Hamilton, New Zealand.

The experimental diets consisted of fresh cut ryegrass and white clover-dominant pasture that was offered at $6 \mathrm{~h}$ intervals (03.00, 09.00, 15.00 and 21.00 hours). Pasture samples were collected and pooled across the two periods before being analysed for nutritional composition by nearinfrared reflectance spectroscopy (NIRSystems Inc., Silver Spring, 20904, MD, USA). The average chemical composition (per $\mathrm{kg}$, DM basis) of the pasture offered, during periods 1 and 2 respectively, was 180 and $150 \mathrm{~g}$ crude protein, 200 and $200 \mathrm{~g}$ soluble carbohydrates, 300 and $280 \mathrm{~g}$ acid-detergent fibre, 500 and $530 \mathrm{~g}$ neutral-detergent fibre and 12.1 and $12.5 \mathrm{MJ}$ metabolisable energy/kg DM.

On day 11 of each period, the experimental animals were fitted with custom-made polyvinyl chloride catheters (length $1.2 \mathrm{~m} ; 1.0 \mathrm{~mm}$ internal diameter $\times 1.5 \mathrm{~mm}$ external diameter; Critchley Electrical Products, Silverwater, NSW, Australia) in the aorta via the costoabdominal (intercostal) artery, and the jugular and mammary (caudal superficial epigastric) veins. The catheters were fitted in the aforementioned vessels following tranquillisation with xylazine hydrochloride $(0.8 \mathrm{ml}$ Rompun $2 \%$; Bayer New Zealand Ltd, Auckland, New Zealand) and local subcutaneous anaesthesia (lignocaine hydrochloride 2\%; Ethical Agents, Auckland, New Zealand). In the case of the costoabdominal artery catheterisation, lignocaine was injected subcutaneously cranial and dorsal to the incision area. Additional local analgesia was provided by injecting lignocaine around the nerve accompanying the artery proximal to the incision area. All catheterisations were carried out using aseptic procedures. Cows were allowed to recover from the surgery for $1 \mathrm{~d}$ before starting blood sampling and tracer infusions. The intercostal catheters were maintained during the two experimental periods, while both venous catheters were removed at the end of the first period and new catheters inserted on day 11 of the second period. The catheters in the artery and mammary vein allowed simultaneous blood sampling to assess the uptake of AA across the mammary gland, whilst the jugular catheter was used for infusing the isotopic tracer. A bolus injection of heparin $(150 \mathrm{IU} / \mathrm{kg}$ live weight; New Zealand Pharmaceuticals Ltd, Linton, New Zealand) was administered before starting blood collection to minimise clot formation in the sampling catheters. Patency of all the catheters was ensured by daily flushing with $3 \mathrm{ml}$ heparinised saline $(200 \mathrm{IU} / \mathrm{ml})$.

Animals were milked twice daily during the whole experiment, except during the last $24 \mathrm{~h}$ of each period, when milking was conducted every $2 \mathrm{~h}$. Animals were machine-milked after an intravenous injection of $1 \mathrm{IU}$ oxytocin (Oxytocin EA; Ethical Agents Ltd, Auckland, New Zealand). To ensure complete removal of milk, a second oxytocin injection (1 IU) was administered and residual milk was removed by hand-stripping.

\section{Measurements}

Whole-body irreversible loss rates (ILR; flux) were measured at the end of each experimental period. AA uptake by the mammary gland was measured and compared with the whole-body flux to obtain an estimation of the partitioning of AA towards milk protein synthesis. DMI was recorded daily. Milk yield during the infusion period was recorded and samples were collected every $2 \mathrm{~h}$ and analysed for $\mathrm{N}$ using macro-Kjeldahl techniques (Barbano, 1994).

Determination of whole-body irreversible loss rate of amino acids. Whole-body ILR of AA was measured using ${ }^{13} \mathrm{C}$-universally labelled AA of algal origin as markers, as described by Lobley et al. (1996).

Preparation of the mixture of ${ }^{13} \mathrm{C}$-universally labelled amino acids. The ${ }^{13} \mathrm{C}$-labelled AA infusates were 
prepared using a modification of the procedure described by Lobley et al. (1996). Briefly, the mixture of $\mathrm{U}^{13} \mathrm{C}$ labelled AA was prepared by hydrolysis of de-starched and de-lipidated labelled Spirulina (Martek Biosciences Corporation, Columbia MD, USA; enrichment $>98 \%$ ). Four $18.75 \mathrm{~g}$ batches of Spirulina were hydrolysed separately in 3.75 litres of boiling $6 \mathrm{M}-\mathrm{HCl}$ containing $25 \mathrm{mg}$ phenol crystals and $500 \mathrm{mg}$ DL-dithiothreitol/l. The hydrolysis was conducted for $22 \mathrm{~h}$ under continuous $\mathrm{N}_{2}$ flow. The resulting hydrolysates were taken to near-dryness (approximately $15 \mathrm{ml}$ final volume) in a rotary evaporator and diluted in $0.1 \mathrm{M}$-sodium phosphate buffer (approximately $60 \mathrm{ml}$ buffer/g Spirulina) and the $\mathrm{pH}$ was adjusted to $7 \cdot 4$. The final infusate was prepared by diluting this solution $(1: 2, \mathrm{v} / \mathrm{v})$ with sterile saline and sodium heparin (400 IU/g final infusate) and filtering through a $0.2 \mu \mathrm{m}$ filter before storage at $-20^{\circ} \mathrm{C}$. Infusates were thawed and re-filtered $(0.2 \mu \mathrm{m}$ filter) before infusion into the experimental animals.

Infusions. On day 14 and 15 of each period, the mixture of $\mathrm{U}^{13} \mathrm{C}$-labelled AA was infused into the jugular vein of two cows for $12 \mathrm{~h}$ (day 14) and two cows for $6 \mathrm{~h}$ (day 15) to determine the whole-body ILR of AA in the experimental animals. The isotope mixture was infused at a rate of $1 \mathrm{ml} / \mathrm{min}$. The concentrations ( $\mathrm{mmol} / \mathrm{l})$ of essential AA (EAA) in the infusate were: histidine (His) 1.2 (SD 0.05); isoleucine (Ile) 5.6 (SD 0.15); leucine (Leu) 8.8 (SD 0.28); lysine (Lys) 3.7 (SD 0.13); methionine (Met) 2.2 (SD 0.06); phenylalanine (Phe) 3.6 (SD 0.13); threonine (Thr) 5.1 (SD 0.16); tyrosine (Tyr) 1.8 (SD 0.07) and valine (Val) $6 \cdot 1($ SD $0 \cdot 20)$

Before the infusion, arterial samples were collected to correct for background abundance of ${ }^{13} \mathrm{C}$ in the blood of the experimental animals. During the isotope infusion, blood was sampled from the intercostal artery and the mammary catheters every $2 \mathrm{~h}$ as $1 \mathrm{~h}$ integrated samples (i.e. continuous sampling for $1 \mathrm{~h}$, no sampling for $1 \mathrm{~h}$ ). Samples were collected at a rate of $1 \mathrm{ml} / \mathrm{min}$ using peristaltic pumps (Desaga GmbH, D-6900 Heidelberg, Germany) into plastic tubes kept on ice with $50 \mu \mathrm{l} \mathrm{Na-EDTA} \mathrm{(satu-}$ rated aqueous solution) added as an anticoagulant. The blood was divided into two subsamples. One subsample was centrifuged at $3270 \mathrm{~g}$ at $4^{\circ} \mathrm{C}$ for $15 \mathrm{~min}$. Plasma was harvested and mixed (10:1, v/v) with a solution of 0.2 M-sodium phosphate buffer containing 0.08 M-DLdithiothreitol. Whole blood in the remaining subsample was haemolysed with deionised water $(1: 1, \mathrm{v} / \mathrm{v})$ and mixed with 0.2 M-sodium phosphate buffer containing $80 \mathrm{~mm}$-DL-dithiothreitol $(0.1 \mathrm{ml}$ phosphate buffer $/ \mathrm{ml}$ blood). Both whole-blood and plasma samples were stored at $-85^{\circ} \mathrm{C}$ until processed for $\mathrm{AA}$ concentration and isotopic enrichment (IE).

\section{Laboratory methods}

Blood, plasma and infusates were processed and analysed for AA concentrations as described previously (PachecoRios et al. 1998).

Sample preparation for stable-isotope determination. The concentration of ${ }^{13} \mathrm{C}$ in the AA in whole blood and plasma was determined in deproteinised samples. Samples of whole blood $(3 \mathrm{ml})$ and plasma $(1.5 \mathrm{ml})$ were deproteinised by ultrafiltration (Centrisart, molecular weight cut-off $10000 \mathrm{Da}$; Sartorius AG, Goettingen D-37070, Germany). AA in the ultrafiltrate were concentrated and cleaned of interfering ions using ion exchange columns (100 mg SCX strong cation exchanger; Alltech Associates, Inc. Deerfield, IL, USA). Columns were preconditioned with $0.005 \mathrm{M}-\mathrm{HCl}(2 \mathrm{ml})$ and deionised water $(4 \mathrm{ml})$ before use. After conditioning, ultrafiltrate $(1 \mathrm{ml})$ was added to the column and washed with $0.01 \mathrm{M}-\mathrm{HCl}(2 \mathrm{ml})$ followed by deionised water $(5 \mathrm{ml})$ to remove sample contaminants. The AA were eluted from the column with $4 \mathrm{M}-\mathrm{NH}_{4} \mathrm{OH}(2 \mathrm{ml})$ into $4 \mathrm{ml}$ vials and then frozen and freeze-dried. Before analysis, the freeze-dried extract was reconstituted in $0.1 \mathrm{M}-\mathrm{HCl}(100 \mu \mathrm{l})$, transferred into a $3 \mathrm{ml}$ tapered vial and carefully reduced to dryness with a stream of $\mathrm{N}_{2}$ gas at $70^{\circ} \mathrm{C}$. To the dried extract, n-tert-butyldimethylsilyl-N-methyl-trifluoroacetamide (50 $\mu$ l, Fluka; Sigma-Aldrich Pty. Ltd, Castle Hill, NSW, Australia), dry acetonitrile $(50 \mu \mathrm{l})$ and dimethylformamide $(50 \mu \mathrm{l})$ were added. The vial was sealed and heated to $70^{\circ} \mathrm{C}$ for $20 \mathrm{~min}$ to convert the AA to their corresponding N,Otert-butyldimethylsilyl (TBDMS) derivatives.

Determination of ${ }^{13} \mathrm{C}$ concentration in blood, plasma and infusates. IE of the samples was measured by GCMS (gas chromatograph model 17A and mass selective detector model QP5050A; Shimadzu Scientific Instruments Ltd, Columbia, MD, USA) equipped with a capillary column (DB-5MS; $30 \mathrm{~m} \times 0.25 \mathrm{~mm}$ internal diameter, $0.25 \mu \mathrm{m}$ film thickness; J\&W Scientific, Folsom, CA, USA) and using $\mathrm{He}$ as the carrier gas. A proportion of TBDMS AA derivative $(1 \mu \mathrm{l})$ was injected using a split ratio of $1: 20$ and injector temperature of $260^{\circ} \mathrm{C}$. Column temperature was initially maintained at $150^{\circ} \mathrm{C}$ for $6 \mathrm{~min}$, then increased to $240^{\circ} \mathrm{C}$ (at $35^{\circ} \mathrm{C} / \mathrm{min}$ ) for $6 \mathrm{~min}$ and then increased to $280^{\circ} \mathrm{C}$ (at $35^{\circ} \mathrm{C} / \mathrm{min}$ ) for $10 \mathrm{~min}$. The mass selective detector was operated in electron impact mode and selected ion monitoring was performed for the $(\mathrm{M}-15)^{+}$and $(\mathrm{M}-57)^{+} \mathrm{m} / \mathrm{z}{ }^{12} \mathrm{C}$ - and ${ }^{13} \mathrm{C}$-TBDMS-AA ion fragments as outlined by Chaves das Neves \& Vasconcelos (1987).

\section{Calculations}

The IE of the AA was calculated using equation 1 (Lobley et al. 1996):

$$
\mathrm{IE}=\frac{\left(R_{t}-R_{0}\right)}{1+\left(R_{t}-R_{0}\right)}
$$

where IE is expressed as mol percent excess and $R$ is the ratio of the mass of the monitored fragment containing the ${ }^{13} \mathrm{C}$ over the mass of the unlabelled molecule. The subscript $t$ refers to the enrichment measured at time $t$ over the infusion period, while the subscript 0 indicates the enrichment measured in background samples (arterial) obtained before the beginning of the isotope infusion.

The values obtained from the different sampling times for each cow were then used to estimate the plateau of IE for individual AA in whole blood and plasma during the course of the ${ }^{13} \mathrm{C}$-labelled AA infusion. An exponential 
model (equation 2) was fitted to the mean of IE obtained from duplicate samples for each AA:

$$
\mathrm{IE}=A \times\left(1-e^{k t}\right),
$$

where $A$ defines the plateau value of IE assuming the enrichment increases at a rate $k$ over time $t$ (Bequette et al. 1998).

The whole-body ILR (mmol/h) for each AA was determined using the model described in equation 3 :

$$
I L R=\left(\frac{I E_{\mathrm{inf}}}{I E_{\text {borp }}}-1\right) \times I R,
$$

in which $I R$ is the infusion rate $(\mathrm{mmol} / \mathrm{h})$ for each AA and $I E_{\text {inf }}$ is the IE of the infusate $(98 \%$; measured in our laboratory) and $I E_{\mathrm{b}}$ or $I E_{\mathrm{p}}$ is the IE of the corresponding AA in blood or plasma at plateau (Lobley et al. 1996).

Partitioning of each AA to the mammary gland was expressed as the percentage contribution of the net uptake of AA to the whole-body ILR, as described by Bequette et al. (1997):

$$
\frac{\text { Net uptake }(N U)}{\text { Whole body ILR }} \times 100 \text {, }
$$

where net uptake is:

$$
\begin{aligned}
N U= & \text { concentration of } A A_{a}-\text { concentration of } A A_{v} \\
& \times M B F
\end{aligned}
$$

given that $A A_{a}$ and $A A_{v}$ represent unlabelled $\mathrm{AA}$ in the arterial and venous samples, respectively from either whole blood or plasma; and $M B F$ is the mammary blood flow estimated using the Fick principle with the arteriovenous differences of Phe and Tyr and the output of these AA in milk (Pacheco-Rios et al. 2001).

\section{Statistical methods}

Estimation of plateau enrichment in samples. Plateau values for the ILR calculation were estimated using the NonLINear regression procedure of SAS (SAS Institute Inc., 1996) by fitting an exponential model (equation 2) to the IE values measured for each cow during the infusion of the ${ }^{13} \mathrm{C}$-labelled AA. For calculation purposes, it was assumed that a plateau was attained when the slope of the regression of enrichment from time 6 to $12 \mathrm{~h}$ was not significantly different from zero.

Treatment and pool effects. Means of the ILR of individual AA for each cow were obtained and then analysed using the MIXED procedure of SAS (SAS Institute Inc., 1996) for a crossover design (Ratkowsky et al. 1993). Treatment, period and type of fluid, and the interaction of type of fluid $\times$ treatment were used as fixed effects; while cow (treatment) was used as a random effect. The treatment effects were tested by using cow (treatment) as the error term and the effects of type of fluid (plasma or blood, where applicable) were evaluated as a repeated measurement with cow (treatment) as a subject. The variance-covariance matrix used was defined as unstructured. The components of the $\mathrm{N}$ balance were analysed using the same model without the repeated measurement statement in the SAS program. Given the limited number of animals that can be used in a study of this nature, significant effects were declared when $P<0.10$ and trends are discussed when $P<0 \cdot 15$.

Ranking of partitioning. The analysis of the partitioning of EAA to the mammary gland was performed on the ranked values using non-parametric ANOVA (SAS Institute Inc., 1996). For each animal and period, the AA were ranked according to their partitioning percentage (i.e. the AA with the highest partition to the mammary gland had a score of 1 , the second highest 2 , and so on).

\section{Animal care}

All procedures used were reviewed and approved by the Animal Ethics Committees of both AgResearch and the Dairy Centre of Excellence.

\section{Results}

Due to problems with one arterial catheter, deep jugular samples were collected from one animal and those samples treated as their arterial counterparts. However, from the analysis of AA concentrations it was apparent that the deep jugular samples were not representative of the arterial supply. Therefore, all the results collected from this one animal were omitted from the statistical analysis reported in Tables 2, 3 and 4.

Compared with the ad libitum period, animals consumed $26 \%$ less DM during the period of DMI restriction (12.3v. $16.7 \mathrm{~kg} \mathrm{DM} / \mathrm{d} ; P<0.01)$. The restriction in DMI was associated with a $13 \%$ decrease in the yield of protein $(0.61$ v. $0.70 \mathrm{~kg} / \mathrm{d} ; P=0.09)$. The decrease in protein yield was, in turn, the combined effect of both decreased milk yield $(19.8 v .21 .6 \mathrm{~kg} / \mathrm{d} ; P=0.14)$ and a decreased concentration of milk protein $(31 \cdot 1 v .32 .8 \mathrm{~g} / \mathrm{kg} ; P=0.09)$.

The dietary restriction caused a lower $\mathrm{N}$ retention (Table 1). There was a significant $(P<0 \cdot 10)$ reduction in $\mathrm{N}$ intake as a consequence of the dietary restriction. This resulted in decreased $(P<0 \cdot 10) \mathrm{N}$ excretion in faeces and urine.

Table 1. Components of the nitrogen balance measurements in four lactating dairy cows fed ad libitum or restricted dry matter intakes during the experimental periods (days 6 to 11)* (Least squares means and standard errors of the mean)

\begin{tabular}{lcccc}
\hline & Ad libitum & Restricted & SEM & $P$ P \\
\hline N intake (g/d) & 0.445 & 0.328 & 0.0083 & 0.01 \\
Milk N (g/d) & 0.111 & 0.097 & 0.0039 & 0.13 \\
Faecal N (g/d) & 0.143 & 0.082 & 0.0094 & 0.04 \\
Urinary N (g/d) & 0.173 & 0.141 & 0.0055 & 0.06 \\
Total N excretion (g/d) & 0.426 & 0.320 & 0.0091 & 0.01 \\
N balance (g/d) & 0.019 & 0.009 & 0.0072 & 0.44 \\
N intake to milk (\%) & 24.9 & 29.3 & 0.51 & 0.03 \\
N intake to faeces (\%) & 31.7 & 24.8 & 1.90 & 0.12 \\
N intake to urine (\%) & 38.8 & 43.3 & 2.73 & 0.37 \\
N retained (\%) & 4.5 & 2.6 & 1.75 & 0.53
\end{tabular}

* For details of diet and procedures, see p. 272.

† Probability of difference between treatments. 
Table 2. Plateau isotopic enrichment $\left({ }^{13} \mathrm{C}\right.$ IE) of amino acids in whole blood or plasma of three dairy cows fed ad libitum or restricted dry matter intakes, as determined from the model $\mathrm{IE}=A \times\left(1-e^{k t}\right)^{*}$

(Least squares means and standard errors of the mean)

\begin{tabular}{|c|c|c|c|c|c|c|c|}
\hline & \multicolumn{2}{|c|}{ Ad libitum } & \multicolumn{2}{|c|}{ Restricted } & \multirow[b]{2}{*}{ SEM } & \multicolumn{2}{|c|}{ Probabilities } \\
\hline & Blood & Plasma & Blood & Plasma & & Diet & Fluid \\
\hline \multicolumn{8}{|l|}{ EAA } \\
\hline Histidine & 0.23 & 0.47 & 0.27 & 0.53 & 0.055 & 0.49 & $<0.01$ \\
\hline Isoleucine & 0.66 & 0.73 & 0.89 & 0.96 & 0.076 & $0 \cdot 10$ & $<0.01$ \\
\hline Leucine & 0.60 & 0.77 & 0.72 & 0.94 & 0.081 & 0.26 & $<0.01$ \\
\hline Lysine & 0.39 & 0.55 & 0.46 & 0.70 & 0.052 & 0.18 & $<0.01$ \\
\hline Methionine & 0.60 & 0.80 & 0.89 & 0.97 & 0.100 & 0.09 & 0.21 \\
\hline Phenylalanine & 0.65 & 0.75 & 0.71 & 0.88 & 0.077 & 0.44 & $<0.01$ \\
\hline Threonine & 0.50 & 0.58 & 0.53 & 0.78 & 0.072 & 0.23 & 0.05 \\
\hline Tyrosine & 0.36 & 0.52 & 0.45 & 0.72 & 0.031 & 0.02 & $<0.01$ \\
\hline Valine & 0.53 & 0.57 & 0.68 & $0 \cdot 74$ & 0.061 & $0 \cdot 14$ & $<0.01$ \\
\hline \multicolumn{8}{|l|}{ NEAA } \\
\hline Alanine & 0.36 & 0.47 & 0.55 & 0.63 & 0.043 & 0.04 & $<0.01$ \\
\hline Glutamic acid & 0.28 & 0.86 & 0.29 & 0.67 & 0.087 & 0.37 & $<0.01$ \\
\hline Glycine & 0.26 & 0.46 & 0.38 & 0.61 & 0.043 & 0.09 & $<0.01$ \\
\hline Proline & 0.51 & 0.88 & 0.68 & 1.09 & 0.060 & 0.06 & $<0.01$ \\
\hline Serine & 0.42 & 0.36 & 0.44 & 0.50 & 0.055 & 0.99 & 0.22 \\
\hline
\end{tabular}

EAA, essential amino acids; NEAA, non-essential amino acids.

${ }^{*}$ For details of calculations, diet and procedures see equation 2 and p. 272.

Table 3. Whole-body irreversible loss rates $(\mathrm{mmol} / \mathrm{h})$ of amino acids calculated from arterial whole blood or plasma ${ }^{13} \mathrm{C}$ isotopic enrichments in three lactating dairy cows fed ad libitum or restricted dry matter intakes*

(Least squares means and standard errors of the mean)

\begin{tabular}{|c|c|c|c|c|c|c|c|}
\hline & \multicolumn{2}{|c|}{ Ad libitum } & \multicolumn{2}{|c|}{ Restricted } & \multirow[b]{2}{*}{ SEM } & \multicolumn{2}{|c|}{ Probabilities } \\
\hline & Blood & Plasma & Blood & Plasma & & Diet & Fluid \\
\hline \multicolumn{8}{|l|}{ EAA } \\
\hline Histidine & 32 & 14 & 27 & 14 & $3 \cdot 2$ & 0.57 & $<0.01$ \\
\hline Isoleucine & 50 & 46 & 38 & 35 & $3 \cdot 6$ & 0.08 & 0.03 \\
\hline Leucine & 84 & 66 & 72 & 55 & 6.9 & 0.28 & $<0.01$ \\
\hline Lysine & 56 & 39 & 47 & 33 & $5 \cdot 1$ & 0.29 & 0.02 \\
\hline Methionine & 23 & 16 & 14 & 15 & 1.6 & 0.06 & 0.05 \\
\hline Phenylalanine & 35 & 28 & 29 & 24 & $3 \cdot 2$ & 0.32 & 0.01 \\
\hline Threonine & 67 & 50 & 59 & 37 & $7 \cdot \overline{1}$ & 0.23 & 0.04 \\
\hline Tyrosine & 29 & 19 & 26 & 16 & $1 \cdot 8$ & 0.24 & $<0.01$ \\
\hline Valine & 69 & 61 & 52 & 49 & $5 \cdot 5$ & 0.12 & $<0.01$ \\
\hline \multicolumn{8}{|l|}{ NEAA } \\
\hline Alanine & 164 & 129 & 123 & 104 & $10 \cdot 8$ & 0.09 & $<0.01$ \\
\hline Glutamic acid & 191 & 72 & 192 & 77 & $13 \cdot 4$ & 0.86 & $<0.01$ \\
\hline Glycine & 182 & 125 & 134 & 83 & $24 \cdot 1$ & 0.14 & 0.09 \\
\hline Proline & 44 & 25 & 35 & 20 & $2 \cdot 8$ & 0.11 & $<0.01$ \\
\hline Serine & 99 & 78 & 73 & 65 & $13 \cdot 8$ & 0.22 & 0.35 \\
\hline
\end{tabular}

EAA, essential amino acids; NEAA, non-essential amino acids.

${ }^{*}$ For details of diet and procedures, see p. 272.

No adverse reactions were observed as result of the infusion of the Spirulina hydrolysate. Most of the AA studied exhibited a rapid increase in ${ }^{13} \mathrm{C}$ enrichment over the first $4 \mathrm{~h}$ of the infusion period, with a discernible plateau attained after this time (Fig. 1).

The data collected from the animals with the $12 \mathrm{~h}$ infusion showed that the CV of the IE was less than $10 \%$ over the period 6 to $12 \mathrm{~h}$ for most of the EAA studied, with exception of Met $(17 \%)$. The regression analysis of IE $v$. time (6 to $12 \mathrm{~h}$ ) revealed that, in most cases, the slope was not significantly different from zero $(P>0.05$; i.e. plateaux were attained).
For all the variables, the interaction between dietary treatment and type of sample was not significant $(P>0 \cdot 15)$.

The ${ }^{13} \mathrm{C}$ enrichment measured in whole blood ranged from 0.23 to 0.89 with the values for His and Met being the extremes. In plasma, the IE ranged from 0.36 (serine; Ser) to 1.09 (proline). Plasma had higher IE for all the AA studied, although the effect was not significant $(P>0 \cdot 10)$ for Met and Ser. Irrespective of the pool studied, the restricted animals had numerically higher IE than the cows with ad libitum intakes; however, the treatment effect attained statistical significance for only some AA (Table 2). 
Table 4. Partitioning (net uptake/irreversible loss rates $\times 100$ ) of amino acids from whole blood and plasma to the mammary gland of three lactating dairy cows fed fresh pasture at ad libitum and restricted intakes*

(Least squares means and standard errors of the mean)

\begin{tabular}{|c|c|c|c|c|c|c|c|}
\hline & \multicolumn{2}{|c|}{ Ad libitum } & \multicolumn{2}{|c|}{ Restricted } & \multirow[b]{2}{*}{ SEM } & \multirow[b]{2}{*}{$P$ diet } & \multirow[b]{2}{*}{ Ranking } \\
\hline & Blood & Plasma & Blood & Plasma & & & \\
\hline \multicolumn{8}{|l|}{ EAA } \\
\hline Histidine & 9 & 19 & 6 & 19 & 1.9 & 0.56 & $9^{d}$ \\
\hline Isoleucine & 31 & 29 & 36 & 32 & $3 \cdot 1$ & 0.36 & $1^{\mathrm{a}}$ \\
\hline Leucine & 24 & 29 & 26 & 32 & $2 \cdot 0$ & 0.43 & $3^{a b}$ \\
\hline Lysine & 25 & 32 & 25 & 35 & $2 \cdot 1$ & 0.47 & $2^{\mathrm{ab}}$ \\
\hline Methionine & 21 & 29 & 26 & 25 & 3.5 & 0.86 & $6^{\mathrm{bc}}$ \\
\hline Phenylalanine & 21 & 21 & 21 & 24 & $2 \cdot 1$ & 0.64 & $7^{\text {cd }}$ \\
\hline Threonine & 11 & 17 & 7 & 19 & 2.5 & 0.90 & $8^{d}$ \\
\hline Tyrosine & 22 & 28 & 25 & 33 & $2 \cdot 4$ & 0.19 & $5^{a b}$ \\
\hline Valine & 25 & 29 & 30 & 29 & $2 \cdot 1$ & 0.31 & $4^{\mathrm{ab}}$ \\
\hline \multicolumn{8}{|l|}{ NEAA } \\
\hline Alanine & 5 & 7 & 5 & 5 & 1.0 & 0.58 & \\
\hline Glutamic acid & 7 & 22 & 10 & 20 & 3.4 & 0.90 & \\
\hline Glycine & 0 & 2 & 3 & 3 & $1 \cdot 7$ & 0.40 & \\
\hline Proline & 7 & 9 & 18 & 17 & $3 \cdot 0$ & 0.93 & \\
\hline Serine & 4 & 7 & 6 & 7 & 1.4 & 0.53 & \\
\hline
\end{tabular}

EAA, essential amino acids; NEAA, non-essential amino acids.

a,b,c,d Rankings within a column for the EAA with unlike superscript letters were significantly different $(P<0.05$, non-parametric ANOVA of ranked values)

${ }^{*}$ For details of diet and procedures, see p. 272.

The ILR calculated using whole-blood IE were higher $(P<0 \cdot 05)$ than those calculated from plasma for all the AA studied with the exception of Ser (Table 3). Irrespective of the type of sample analysed, the animals undergoing the dietary restriction had ILR that were numerically lower than those measured in animals fed ad libitum.

Depending on the AA and pool analysed (whole blood or plasma), the ILR of AA in restricted animals was 65-95\% of that observed in ad libitum animals (average 89 and $80 \%$ using whole-blood and plasma IE, respectively). However, this effect was statistically significant $(P<0 \cdot 10)$ for Ile, Met and alanine only. Glutamic acid (Glu) was the only AA for which the ILR was numerically higher in restricted animals. In those cases, the ILR of Glu in restricted animals was 101 and $107 \%$ (whole blood and plasma, respectively) of that measured in the ad libitum group.

The partitioning of AA to the mammary gland ranged from 6 to $36 \%$ and 17 to $35 \%$ as calculated from wholeblood or plasma ILR, respectively (Table 4). For the non-essential AA, the partitioning to the mammary gland was between 0 and $22 \%$, and for most of those AA it was below $10 \%$. Partitioning for most EAA was remarkably similar for ad libitum and restricted animals, and in many cases was similar when the calculation was done using whole blood or plasma. Ile, Lys, Leu and Val, in that order, were the AA with the highest partitioning to the mammary gland. This finding was consistent between animals and treatments.

\section{Discussion}

The milk production recorded during the present study is representative of the performance of dairy cows grazing fresh pastures during spring in New Zealand. As a comparison, the average production of the parent herd (from which the experimental animals originated) under normal grazing and management practices during the period of the present study was $20 \cdot 3 \mathrm{~kg}$ milk/d (n 261). Therefore, it is possible to conclude that all the reported results are reasonably representative of the conditions encountered in dairy cows fed fresh pasture in New Zealand.

The use of Spirulina-derived ${ }^{13} \mathrm{C}$-labelled AA has been a valuable tool to estimate simultaneously the fluxes of AA in different tissues and species (Lobley et al. 1996; Bequette et al. 1997). To our knowledge, the present study represents the first report of such measurements in lactating dairy cows fed fresh pasture.

The uptake of AA by the mammary gland for milk protein synthesis represented up to $36 \%$ of the whole-body flux of AA in the lactating cows fed fresh pasture.

The validity of the ILR estimation relies on the assumption that the IE of plasma is representative of steady-state conditions during the measurement period (Lobley, 1993). The data collected from the animals with the $12 \mathrm{~h}$ infusion had a CV for the IE of less than $10 \%$ over the period 6 to $12 \mathrm{~h}$ for most of the AA studied, with the exception of Met (CV 17\%). This finding, together with the sharp increase in ${ }^{13} \mathrm{C}$ enrichment measured during the first $4 \mathrm{~h}$ of the infusion (Fig. 1), indicated that enrichment plateaux were attained for the AA studied in the cows receiving the $6 \mathrm{~h}$ infusion.

The reported presence of D-isomers of AA in the Spirulina hydrolysates has to be borne in mind when interpreting the ILR values obtained in the present study. Using a similar technique to produce the algal infusates, Bequette et al. (1997) reported that up to $20 \%$ of the Lys in the hydrolysate was present as the D-isomer, while for the rest of the AA the contribution of D-isomers was less than $4 \%$. 

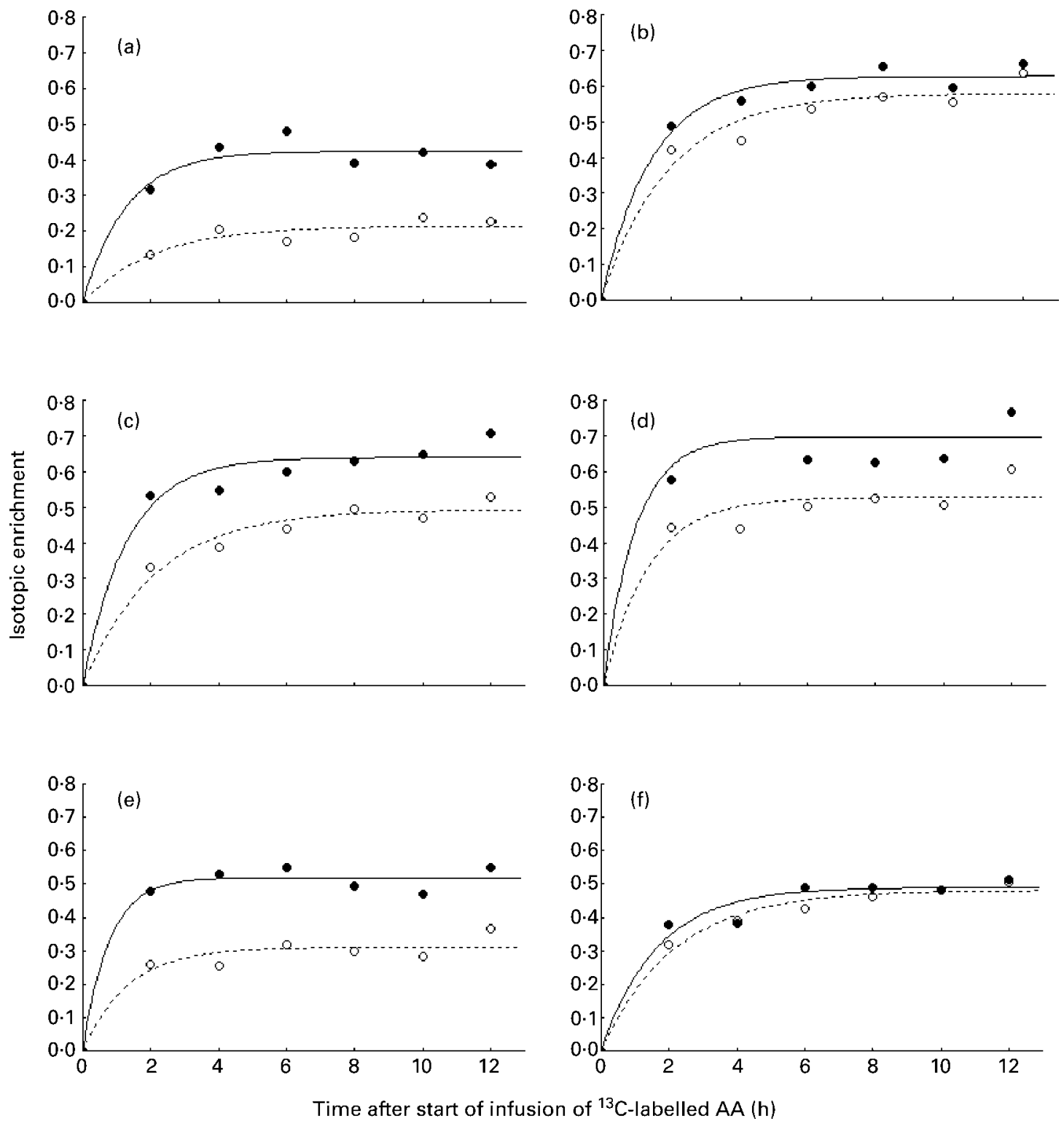

Fig. 1. Examples of the isotopic enrichment (IE) curves for histidine (a), isoleucine (b), leucine (c), methionine (d), tyrosine (e) and valine (f), as measured in whole blood ( $($ ) or plasma $(\bullet)$ in one cow in the ad libitum treatment group. AA, amino acid. Also shown are the fitted lines from IE $=A \times\left(1-e^{k t}\right)$ to determine the plateau values in whole blood $(---)$ and plasma $(-)$, where $A$ defines the plateau value of IE assuming the enrichment increases at a rate $k$ over time $t$ (Bequette et al. 1998).

In the present study, the infusates were not analysed for the presence of D-isomers. Given the results observed by other researchers using similar techniques, the value of ILR for Lys may be an underestimation of its true value. For the rest of the AA, the bias arising from the presence of $\mathrm{D}$-isomers would be less than $5 \%$.

The variation in IE observed between individual AA and between whole blood and plasma is comparable to that in previous studies using the same technique in sheep and goats. Assuming that the composition of the Spirulina hydrolysates used in the present study was similar to those used in sheep (Lobley et al. 1996) and goats (Bequette et al. 1997), the variation in IE between the studies is most probable from inter-species variation in AA concentrations. In the present study, the measured IE is compatible with the relative AA concentrations measured in whole blood and plasma (i.e. the higher the concentration of unlabelled AA, the lower the measured enrichment). Whole-blood IE ranged from 0.50 (His) to 0.92 (Ile, Val) of the IE measured in plasma. As the isotopes are infused into the plasma, it is expected that a higher IE would be measured in this pool. The lower IE in whole blood compared with plasma samples has been attributed to either an incomplete equilibrium across the erythrocyte membrane or the dilution of intracellular AA with unlabelled molecules originating from peptide hydrolysis inside the erythrocyte (Backwell et al. 1994). The higher IE measured in plasma ultimately translates into an ILR value that provides the minimum estimate of whole-body flux of AA (Lobley et al. 1996). Nevertheless, 
it is considered that the use of plasma ILR as a precursor pool provides a better approximation to the 'true' partitioning, as the mammary gland obtains AA mainly from this pool (Pacheco-Rios et al. 1999; Mackle et al. 2000). Furthermore, plasma IE is a better indicator of the labelling of the mammary intracellular pool, by comparison of the IE of whole blood, plasma and casein (Backwell et al. 1996).

Another methodological consideration is related to the site of infusion of the tracer. It has been reported that up to $65 \%$ of the AA-N appearing in the portal circulation is removed by the liver (Lescoat et al. 1996). When the tracer is infused directly into the peripheral circulation (as in the present study) it is not possible to account for the moderating effect of the liver as a result of the first-pass removal of AA from the portal circulation (Bruss \& Black, 1982).

The ILR of AA measured in the present study are comparable when expressed on a metabolic weight basis to those obtained in lactating dairy goats (Bequette et al. 1997) using the same type of algal tracer. Studies on AA fluxes in dairy cows have been limited to single-AA tracers (His, $89 \mu \mathrm{mol} / \mathrm{h}$ per $\mathrm{kg}$ live weight (LW) $)^{0.75}$ (Bruss \& Black, 1982); Leu, $890 \mu \mathrm{mol} / \mathrm{h}$ per kg LW ${ }^{0.75}$ (Bequette et al. 1996b)). Thus, the present study represents, to our knowledge, the first report of simultaneous estimation of an array of AA in lactating dairy cows. Despite the differences in methodology and amount of tracer used, the results obtained here (His, $133 \mu \mathrm{mol} / \mathrm{h}$ per $\mathrm{kg} \mathrm{LW}{ }^{075}$;

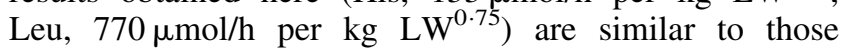
reported in the aforementioned studies (Bruss \& Black, 1982; Bequette et al. 1996b).

For all AA, dietary restriction resulted in a numerical decrease in ILR irrespective of the type of sample (whole blood or plasma) analysed. Similar effects of feed intake on Leu ILR have been reported in beef cattle (Hammond et al. 1987; Lobley et al. 1987; Lapierre et al. 1996, 1999), sheep (Liu et al. 1995) and dairy goats (Riis,
1988). The only exception to this finding was Glu, for which the ILR in restricted animals was numerically higher. Although the transfer of ${ }^{13} \mathrm{C}$ from glutamine (Gln) that can occur during sample preparation for GC-MS analysis may confound the IE for Glu, this effect would appear equally in both treatments. Thus, this finding could be explained in terms of the important role of Glu and Gln in transport of $\mathrm{N}$ between organs (Black et al. 1990; Lacey \& Wilmore, 1990). In contrast to the rest of the AA, the liver releases Glu and Gln to the peripheral circulation (Lobley et al. 1996; Lopez et al. 1998). During diet deprivation, the hepatic release of these two AA has been reported to increase in rats (Lopez et al. 1998) as a means of channelling $\mathrm{N}$ originating from tissue protein mobilisation (particularly from the muscle). Therefore, the numerical increase in the whole-body flux of Glu measured in the present experiment could be attributed to the mobilisation of body reserves as a result of the dietary restriction.

Based on the two-compartment model described by (Lobley, 1993), the ILR represents the sum of the net fluxes of AA utilised for protein synthesis and oxidation. Under steady-state conditions, the ILR can be equated to the sum of AA absorbed from the lumen of the gastrointestinal tract (GIT) and those originating from protein breakdown in the tissues (protein turnover). This model was used to estimate the contribution of each of those four processes (absorption from the GIT, oxidation, whole-body protein synthesis and degradation) in the protein metabolism of the experimental animals (Table 5).

Kolver et al. (1999) measured the flows of AA to the small intestine of dairy cows using the same pasture, treatments and experimental design as those described here. Based on their measurement of duodenal flow of AA and using an average of the intestinal absorption rates for AA in ruminants (Armstrong, 1973; Stern et al. 1985), it was possible to obtain an estimate of the apparent absorption

Table 5. Estimation of the contribution of essential amino acids absorbed or protein breakdown to the amino acid flux and the partitioning of this flux between protein synthesis and oxidation in lactating dairy cows fed fresh pasture*

\begin{tabular}{|c|c|c|c|c|c|c|c|c|}
\hline & \multicolumn{4}{|c|}{ Proportion of the ILR contributed by: } & \multicolumn{4}{|c|}{ Proportion of the ILR partitioned to: } \\
\hline & \multicolumn{2}{|c|}{ Net absorption† } & \multicolumn{2}{|c|}{ Protein breakdown $\ddagger$} & \multicolumn{2}{|c|}{ Protein synthesis $\S$} & \multicolumn{2}{|c|}{ Oxidation\| } \\
\hline & Ad libitum & Restricted & Ad libitum & Restricted & Ad libitum & Restricted & Ad libitum & Restricted \\
\hline His & 0.40 & 0.31 & $0 \cdot 60$ & 0.69 & 0.94 & 0.95 & 0.06 & 0.05 \\
\hline Ile & $0 \cdot 30$ & 0.27 & 0.70 & 0.73 & 0.93 & 0.96 & 0.07 & 0.04 \\
\hline Leu & 0.41 & 0.38 & 0.59 & 0.62 & 0.90 & 0.91 & $0 \cdot 10$ & 0.09 \\
\hline \multicolumn{9}{|l|}{ Lys: } \\
\hline Uncorrected & 0.48 & 0.46 & 0.52 & 0.53 & 0.90 & 0.91 & 0.10 & 0.09 \\
\hline Corrected & 0.41 & 0.39 & 0.59 & 0.61 & 0.92 & 0.92 & 0.08 & 0.08 \\
\hline Met & 0.30 & 0.26 & 0.70 & 0.74 & 0.95 & 0.97 & 0.05 & 0.03 \\
\hline Phe & 0.34 & 0.32 & 0.66 & 0.68 & 0.92 & 0.94 & 0.08 & 0.06 \\
\hline Thr & 0.43 & 0.47 & 0.57 & 0.53 & 0.77 & 0.74 & 0.23 & 0.26 \\
\hline Tyr & 0.39 & 0.38 & 0.61 & 0.62 & 0.97 & 0.97 & 0.03 & 0.03 \\
\hline Val & 0.33 & 0.30 & 0.67 & 0.70 & 0.90 & 0.94 & 0.10 & 0.06 \\
\hline
\end{tabular}

ILR, irreversible loss rate, His, histidine, Ile, isoleucine, Leu, leucine, Lys, lysine, Met, methionine, Phe, phenylalanine, Thr, threonine, Tyr, tyrosine, Val, valine ${ }^{*}$ Calculated from the ILR measured using the isotopic enrichment of arterial plasma as precursor pool.

† Calculated from the duodenal amino acid flows reported by (Kolver et al. 1999) and the intestinal absorption coefficient reported by Armstrong (1973) and Stern et al. (1985).

¥ Calculated as ILR - net absorption. Whole body amino acid composition from Gibb et al. (1992) and MacRae et al. (1993).

$\S$ Calculated from $\mathrm{N}$ retention (from $\mathrm{N}$ balance) + milk protein output + protein breakdown.

$\|$ Calculated as ILR - protein synthesis.

I A correction (ILR Lys $\times 1.2$ ) was made to account for the presence of D-Lys in the isotopic tracer infused. 
of AA and, by difference, the contribution of tissue turnover to ILR. Absorption of AA from the GIT accounted, on average, for $35 \%$ (range 26 to $48 \%$; Table 5) of the ILR measured from arterial plasma IE. The results obtained are comparable to those reported in the few studies in which GIT flows and ILR of AA were measured simultaneously. For instance, Egan et al. (1983) reported that absorption from the GIT represented $30 \%$ of the Thr ILR measured in mature sheep. Liu et al. (1995) reported that, for Leu, the contribution of GIT absorption ranged from 2 to $34 \%$ of the ILR measured in lambs. Comparing the amounts absorbed from the GIT and partitioned to the mammary gland (Table 4), it appears that mammary utilisation by itself may account for a large proportion of the absorbed His $(78 \%)$, Ile $(76 \%)$, Lys $(75 \%)$, Met $(81 \%)$ and Tyr $(86 \%)$. Although the process of tissue turnover represents a major contribution to the total body flux of these AA (up to $74 \%$ ), it could be hypothesised that their dietary supply could be limiting milk protein synthesis.

The other two terms in the model, namely protein synthesis and oxidation, can be estimated using the $\mathrm{N}$ retention calculated from the $\mathrm{N}$ balance (Lapierre et al. 1996) corrected to estimate total protein accretion (MacRae et al. 1993). Black et al. (1990) and Bequette et al. (1998) have suggested that the AA that are most likely to be limiting milk protein synthesis will be conserved relative to others and thus least oxidised. Based on that premise, His, Met and Tyr are the AA most likely to be limiting protein synthesis in the present study. Despite the limitations of the oxidation estimates described in the present study, the results were comparable to studies in which individual radioactive tracers were used to estimate oxidation of AA to $\mathrm{CO}_{2}$ (Black et al. 1990).

Kolver et al. (1999) reported a $23 \%$ (range 18 to $30 \%$, depending on the AA) reduction in AA flow to the small intestine of restricted animals in the study run parallel to this one. In the present study, the reduction in ILR associated with the dietary restriction was, on average, $21 \%$ (range 11 to $41 \%$ ) and $18 \%$ (range 3 to $30 \%$ ) as calculated from whole blood and plasma, respectively.

Partitioning of AA to the mammary gland ranged from 17 to $35 \%$ of the whole-body ILR depending on the AA. This finding is similar to the partitioning values reported for dairy goats (Bequette et al. 1997) and congruent with the major role of the mammary gland in the AA economy of the lactating ruminant (Champredon et al. 1990; Baracos et al. 1991).

Total EAA uptake by the mammary gland was, on average, $28 \%$ of the EAA whole-body flux. Deviations on the partitioning from these percentages can depict the AA requirements of the mammary gland relative to the whole-body flux of that AA. For instance, the branchedchain AA (BCAA) and Lys utilised by the mammary gland represented up to $35 \%$ of the whole-body ILR (Table 4). These four AA accounted for approximately $60 \%$ of the total EAA in milk protein. Besides their role in protein synthesis, the BCAA are also used in the mammary gland to yield $\mathrm{C}$ skeletons and $\alpha$-amino groups for the synthesis of non-essential AA, mainly Glu and aspartic acid (Wohlt et al. 1977; Lobley, 1992). These two major metabolic pathways (milk protein synthesis plus mammary catabolism) may explain the high partitioning to the mammary gland observed for these AA. Experiments with supplementary BCAA have failed to show a positive effect of extra supply of BCAA on milk protein synthesis (Mackle et al. 1999). However, the objective of their experiment was to assess the effect of BCAA supplementation with concentrate diets formulated to exceed the cows' requirements for metabolisable protein and energy. Similarly, studies on the Leu metabolism of lactating ruminants (Bequette et al. 1996a,b) have been conducted using concentrate-rich diets. More research is required to quantify BCAA metabolism in pasture-fed animals in order to ascertain their role as potentially limiting AA.

In contrast to the BCAA, Thr and His are present in smaller proportions in milk protein, which may explain their lower partitioning to the mammary gland. However, in the case of His, for which measured uptake by the mammary gland did not account for its output in milk protein, the low partitioning to the mammary gland may indicate that other functions in the body have priority over the lactating mammary gland. His is not a major precursor for the synthesis of non-essential AA (Bruss \& Black, 1982) or a major energy contributor (Black et al. 1990). In fact, according to Black et al. (1990) His is the AA with the lowest oxidation in the lactating dairy cow. These findings would suggest that His is spared for the synthesis of protein and specific metabolites (for example, histamine involved in mammary blood flow regulation; Bequette et al. 1998). More research is required to determine whether the low partitioning of His to the mammary gland is the result of competition by other metabolic pathways or rather the reflection of limited ability by the appropriate AA transport system in the mammary epithelial cell (Baumrucker, 1985).

In the present study, it has been shown that it is possible to obtain adequate estimates of the whole-body AA fluxes in large ruminants using relatively low amounts of tracer. More research is still required on the metabolic fate of certain AA (including His, Ile, Phe and Tyr) to increase our understanding of the metabolic processes underlying milk protein synthesis.

\section{Acknowledgements}

This research was supported by the New Zealand Foundation for Research, Science and Technology. The authors thank the Dairy Centre of Excellence for providing the facilities, and Vicki Carruthers, David Phipps, Erna Jansen and Peter Neil for their skilful assistance. The assistance of Tricia Harris, Jason Peters and Penny Back (Nutrition and Behaviour, AgResearch Grasslands) is gratefully appreciated. The comments and questions of Dr Hélène Lapierre (Agri-Food and Agriculture Canada) are very much appreciated. D. P. thanks the National Autonomous University of Mexico for providing the scholarship for his studies.

\section{References}

AFRC (1993) Energy and Protein Requirements of Ruminants. An Advisory Manual Prepared by the AFRC Technical Committee on Responses to Nutrients. Wallingford, UK: CAB International. 
Armstrong DG (1973) The uptake of amino acids by the small intestine of the ruminant animal. In Production Disease in Farm Animals, pp. 43-53 [JM Payne, KG Hibbitt and BF Sansom, editors]. London, UK: Baillière Tindall.

Backwell FRC, Bequette BJ, Wilson D, et al. (1994) Utilization of dipeptides by the caprine mammary gland for milk protein synthesis. Am J Physiol 267, R1-R6.

Backwell FRC, Bequette BJ, Wilson D, et al. (1996) Evidence for the utilization of peptides for milk protein synthesis in the lactating dairy goat in vivo. Am J Physiol 271, R955-R960.

Baracos VE, Brun-Bellut J \& Marie M (1991) Tissue protein synthesis in lactating and dry goats. Br J Nutr 66, 451-465.

Barbano DM (1994) Reference and routine methods for measurement of $\mathrm{N}$ fractions. Protein definition. In International Dairy Federation Special Issue no. 9403, pp. 40-55. Brussels, Belgium: International Dairy Federation.

Bauman DE \& Currie WB (1980) Partitioning of nutrients during pregnancy and lactation: A review of mechanisms involving homeostasis and homeorhesis. J Dairy Sci 63, 1514-1529.

Baumrucker CR (1985) Amino acid transport systems in bovine mammary tissue. J Dairy Sci 68, 2436-2451.

Bequette BJ, Backwell FRC, Calder AG, et al. (1997) Application of a U- ${ }^{13} \mathrm{C}$-labeled amino acid tracer in lactating dairy goats for simultaneous measurements of the flux of amino acids in plasma and the partition of amino acids to the mammary gland. J Dairy Sci 80, 2842-2853.

Bequette BJ, Backwell FRC \& Crompton LA (1998) Current concepts of amino acid and protein metabolism in the mammary gland of the lactating ruminant. J Dairy Sci 81, 2540-2559.

Bequette BJ, Backwell FRC, Dhanoa MS, et al. (1994) Kinetics of blood free and milk casein-amino acid labelling in the dairy goat at two stages of lactation. Br J Nutr 72, 211-220.

Bequette BJ, Backwell FRC, MacRae JC, et al. (1996a) Effect of intravenous amino acid infusion on leucine oxidation across the mammary gland of the lactating goat. J Dairy Sci 79, 2217-2224

Bequette BJ, Metcalf JA, Wray-Cahen D, et al. (1996b) Leucine and protein metabolism in the lactating dairy cow mammary gland: responses to supplemental dietary crude protein intake. J Dairy Res 63, 209-222.

Black AL, Anand RS, Bruss ML, Brown CA \& Nakagiri JA (1990) Partitioning of amino acids in lactating cows: Oxidation to carbon dioxide. J Nutr 120, 700-710.

Boirie Y, Fauquant J, Rulquin H, Maubois JL \& Beaufrere B (1995) Production of large amounts of $\left[{ }^{13} \mathrm{C}\right]$ leucine-enriched milk proteins by lactating cows. $J$ Nutr 125, 92-98.

Bruss ML \& Black AL (1982) Estimation of plasma histidine flux in cows. J Nutr 112, 574-583.

Carruthers VR \& Neil PG (1997) Milk production and ruminal metabolites from cows offered two pasture diets supplemented with non-structural carbohydrate. NZ J Agric Res 40, 513-521.

Champredon C, Debras E, Mirand PP \& Arnal M (1990) Methionine flux and tissue protein synthesis in lactating and dry goats. J Nutr 120, 1006-1015.

Chaves das Neves HJ \& Vasconcelos AMP (1987) Capillary gas chromatography of amino acids, including asparagine and glutamine: sensitive gas chromatographic-mass spectrometric and selected ion monitoring gas chromatographic-mass spectrometric detection of the N,O(S)-tert.-butyldimethylsilyl derivatives. J Chromatogr 392, 249-258.

Crompton LA \& Lomax MA (1993) Hindlimb protein turnover and muscle protein synthesis in lambs: a comparison of techniques. Br J Nutr 69, 345-358.

Egan AR, MacRae JC \& Lamb CS (1983) Threonine metabolism in sheep. 1. Threonine catabolism and gluconeogenesis in mature Blackface wethers given poor quality hill herbage. Br J Nutr 49, 373-383.
Gibb MJ, Ivings WE, Dhanoa MS \& Sutton JD (1992) Changes in body components of autumn-calving Holstein-Friesian cows over the first 29 weeks of lactation. Anim Prod 55, 339-360.

Hammond AC, Huntington GB, Reynolds PJ, Tyrrell HF \& Eisemann JH (1987) Absorption, plasma flux and oxidation of L-leucine in heifers at two levels of intake. J Anim Sci 64, 420-425.

Kolver ES, Carruthers VR, Neil PG, De Veth MJ, Jansen EBL \& Phipps DE (1999) Amino acid supply to the small intestine of dairy cows fed pasture. Proc NZ Soc Anim Prod 59, 180-183.

Lacey JM \& Wilmore DW (1990) Is glutamine a conditionally essential amino acid? Nutr Rev 48, 297-309.

Lapierre H, Bernier JF, Dubreuil P, et al. (1999) The effect of intake on protein metabolism across splanchnic tissues in growing beef steers. Br J Nutr 81, 457-466.

Lapierre H, Pelletier G, Ouellet DR, Lobley GE \& Bernier JF (1996) Measuring leucine flux and protein metabolism with carbon-13 isotope in growing cattle. Can J Anim Sci 76, $259-262$.

Lescoat P, Sauvant D \& Danfær A (1996) Quantitative aspects of blood and amino acid flows in cattle. Reprod Nutr Dev 36, $137-174$.

Liu SM, Lobley GE, MacLeod NA, Kyle DJ, Chen XB \& Ørskov ER (1995) Effects of long-term protein excess or deficiency on whole-body protein turnover in sheep nourished by intragastric infusion of nutrients. Br J Nutr 73, 829-839.

Lobley GE (1992) Control of the metabolic fate of amino acids in ruminants: a review. J Anim Sci 70, 3264-3275.

Lobley GE (1993) Protein metabolism and turnover. In Quantitative Aspects of Ruminant Digestion and Metabolism, pp. 313-339 [JM Forbes and J France, editors]. Wallingford, UK: CAB International.

Lobley GE, Connell A \& Buchan V (1987) Effect of food intake on protein and energy metabolism in finishing steers. Br J Nutr 57, 457-465.

Lobley GE, Connell A, Revell DK, Bequette BJ, Brown DS \& Calder AG (1996) Splanchnic-bed transfers of amino acids in sheep blood and plasma, as monitored through use of multiple U- ${ }^{13}$ C-labelled amino acid mixture. Br J Nutr 75, 217-235.

Lopez HW, Moundras C, Morand C, Demigné C \& Rémésy C (1998) Opposite fluxes of glutamine and alanine in the splanchnic area are an efficient mechanism for nitrogen sparing in rats. J Nutr 128, 1487-1494.

Mackle TR, Dwyer DA \& Bauman DE (1999) Effects of branched-chain amino acids and sodium caseinate on milk protein concentration and yield from dairy cows. J Dairy Sci 82, $161-171$.

Mackle TR, Dwyer DA, Ingvartsen KL, Chouinard PY, Ross DA \& Bauman DE (2000) Evaluation of whole blood and plasma in the interorgan supply of free amino acids for the mammary gland of lactating dairy cows. J Dairy Sci 83, 1300-1309.

MacRae JC, Walker A, Brown D \& Lobley GE (1993) Accretion of total protein and individual amino acids by organs and tissues of growing lambs and the ability of nitrogen balance techniques to quantitate protein retention. Anim Prod 57, 237-245.

National Research Council (2001) Nutrient Requirements of Dairy Cattle, 7th revised ed. Washington, DC: National Academy Press.

Pacheco-Rios D, Mackenzie DDS \& McNabb WC (2001) Comparison of two variants of the Fick principle for estimation of mammary blood flow in dairy cows fed two levels of dry matter intake. Can J Anim Sci 81, 57-63.

Pacheco-Rios D, McNabb WC, Cridland S, Barry TN \& Lee J (1998) Arterio-venous differences of amino acids across the mammary gland of cows fed fresh-pasture at two levels of dry matter intake during early lactation. Proc NZ Soc Anim Prod 58, 98-101. 
Pacheco-Rios D, Treloar BP, Lee J, Barry TN \& McNabb WC (1999) Amino acid utilisation by the mammary gland: Whole blood versus plasma free amino acid pools. Proc NZ Soc Anim Prod 59, 62-65.

Ratkowsky DA, Evans MA \& Alldredge JR (1993) Cross-over Experiments: Design, Analysis, and Application. New York, NY: Marcel Dekker, Inc..

Reeds PJ (1992) Isotopic estimation of protein synthesis and proteolysis in vivo. In Modern Methods in Protein Nutrition and Metabolism, pp. 249-273 [S Nissen, editor]. San Diego, CA: Academic Press.

Riis PM (1988) Nitrogen balance, amino acid flux rates and rates of whole body protein synthesis in lactating and in pregnant goats at different energy intakes. J Anim Physiol Anim Nutr 60, 86-95.

SAS Institute Inc. (1996) SAS User's Guide 6.12. Cary, NC: SAS Institute Inc.

Stern MD, Santos KA \& Satter LD (1985) Protein degradation in rumen and amino acid absorption in small intestine of lactating dairy cattle fed heat-treated whole soybeans. J Dairy Sci $\mathbf{6 8}$, $45-56$.

Wohlt JE, Clark JH, Derrig RG \& Davis CL (1977) Valine, leucine and isoleucine metabolism by lactating bovine mammary tissue. J Dairy Sci 60, 1875-1882. 